\title{
Reconsidering the Marxist-Anarchist Controversy in and Through Radical Praxis: Lessons Taken from the Greek Uprising, December 2008
}

\author{
Christos Memos ${ }^{1}$
}

This paper reflects on the Greek revolt of December 2008 and reexamines the dispute between Marxism and anarchism in and through the social unrest. It argues that their polemic and intolerance should not be perceived as established and unchanging. Throughout the uprising, both Marxists and anarchists created a space of openness, united action and active solidarity overcoming their sectarianism and closure. The study considers that the two opposing currents could learn valuable lessons and draw significant conclusions from the radical practice of the insurgents concerning the critical organizational issue and the means-end relationship. It argues, also, that the revolted questioned the existing Marxist and anarchist presuppositions as regards the issues of state and time. The paper maintains that the continuation of the Marxist-anarchist conflict perpetuates the crisis of the international radical movement. It concludes that both Marxism and anarchism could play a constructive role in order to form a new radical alternative and return to the practical and theoretical broadmindedness of the First International. [Article copies available for a fee from The Transformative Studies Institute. E-mail address: journal@transformativestudies.org Website: http://www.transformativestudies.org (C2010 by The Transformative Studies Institute. All rights reserved.]

KEYWORDS: Marxism, Anarchism, Greek uprising.

\footnotetext{
${ }^{1}$ Christos Memos teaches at the Department of Politics, University of York (UK), where he completed his $\mathrm{PhD}$ thesis entitled 'The Social and Political Theory of Axelos, Castoriadis and Papaioannou: A Critical Assessment of Marxism and Marx'. His research interests include social and political theory; history of political thought; Marx and critical Marxism; anarchism; social movements. His recent publications include: 'Dignified Rage, Insubordination and Militant Optimism', Ephemera: Theory and Politics in Organization, 2009, 9(3), 219-233; 'Neoliberalism, Identification Process and the Dialectics of Crisis', International Journal of Urban and Regional Research, 2010, 34(1), 210-216. Address correspondence to: Christos Memos; e-mail: cm193@york.ac.uk.
} 